\title{
Social play traits and environmental exploration in beagle and fox terriers' puppies
}

\author{
Koscinczuk, P.; Alabarcez, M.N.; Cainzos, R.P. \\ Department of Clinical, Faculty of Veterinary Medicine, Northeast National University (UNNE), \\ Sargento Cabral 2139 (3400), Corrientes, Argentine, Tel.+54-3783-42-5753 int.156. \\ E-mail: pkoscinczuk@vet.unne.edu.ar
}

\begin{abstract}
Koscinczuk, P.; Alabarcez, M.N.; Cainzos, R.P.: Social play traits and environmental exploration in beagle and fox terriers' puppies. Rev. vet. 26: 1, 33-37, 2015. Play is one of the most frequent behaviors during the development of animals. Socialization games as well as the use of different objects during games were observed in 32 weeks-old beagles and fox terriers' puppies to evaluate differences among breeds and sexes. All the mothers belonged to the same kennel. Three sessions of 15 min each were recorded at 12:00 h in three consecutive days. All the puppies were video recorded at the same time covering all the area where they were playing, without a blind spot. Then, each individual was observed from a PC monitor using a focal, direct and continuous sampling. Activities were divided in social (when interaction took place between two or more puppies) and individual (when only one puppy was involved). At 45 days old, 8 types of social activities (visual contact, tactile contact, race, jump, bite, chase, pull, competition) and 3 types of individual situations (gnawing, exploring, and sniffing) were registered. Among all the interactions $(1,269)$, we identified $875(76.48 \%)$ as social activities and $394(23.51 \%)$ as individual activities. Only one activity (sniffing) was statistically different between sexes. Females sniffed the environment more often than males $(\mathrm{p}<0.007)$. In both breeds, social activities occurred more frequently than individual activities $(\mathrm{p}=0.96$ ), but breeds do show differences during games. The ranking of activities for beagle puppies $(\mathrm{n}=16)$ according to frequency was: tactile contact, races, visual contact, bite and exploration. When comparing activities, beagles performed more activities such as pulling and winning objects $(\mathrm{p} \leq 0.01)$, and they showed higher interest in gnawing ornamental plants and grass $(\mathrm{p}<0.05)$ than the fox terriers. Ranking of frequency for fox terrier puppies $(\mathrm{n}=16)$ was: race, tactile and visual contact, exploration, and chase. Social activities of visual contact, race and chase were more significant in fox terrier puppies $(p \leq 0.01)$. When considering individual activities, fox terrier puppies were more interested in exploring the garden compared to beagles $(\mathrm{p}=0.01)$. At this age, the observations of natural or spontaneous play behaviors could be considered as an approach for future behavioral patterns, taking into account the differences considering gender and breed for beagle and fox terrier puppies.
\end{abstract}

Key words: dog, behaviour, social and individual activities, sexes and breeds differences.

\begin{abstract}
Resumen
Koscinczuk, P.; Alabarcez, M.N.; Cainzos, R.P.: Características de los juegos sociales y exploración del entorno en cachorros beagle y fox terriers. Rev. vet. 26: 1, 33-37, 2015. El juego constituye una de las conductas más frecuente durante el período de desarrollo de los caninos. Con el objetivo de evaluar diferencias entre razas y sexos, juegos sociales y con objetos fueron observados en cachorros de razas beagle y fox terrier a las 32 semanas de nacidos. Todas las madres pertenecían al mismo criadero. En 3 días consecutivos se filmaron tres sesiones de $15 \mathrm{~min}$ a las 12:00 h. Todos los cachorros fueron filmados al mismo tiempo, cubriendo toda el área donde ellos jugaban, sin dejar espacios ciegos. Así, cada individuo fue estudiado con un monitor de PC a través de un registro focal, directo y continuo. Las actividades fueron divididas en social, cuando la acción tuvo lugar entre dos o más cachorros, e individual cuando involucró solamente un cachorro. A los 45 días de edad, fueron registrados 8 tipos de actividades sociales (contactos visuales, contactos táctiles, carreras, saltos, mordiscos, persecuciones, tironeos, competencias) y 3 tipos de acciones individuales (roer, explorar y olfatear). De todos los contactos registrados (1.269), 875 de ellos (76,48\%) fueron identificados como
\end{abstract}


actividades sociales y $394(23,51 \%)$ como actividades individuales. Sólo una actividad (olfatear) fue estadísticamente diferente entre los sexos. Las hembras olfatearon su entorno más a menudo que los machos $(\mathrm{p}<0,007)$. En ambas razas, las actividades sociales ocurrieron con mayor frecuencia que las actividades individuales $(\mathrm{p}=0,96)$, pero las razas mostraron diferencias durante las actividades de jugueteo. Acorde a la frecuencia registrada, el ranking de actividades de los cachorros beagle $(\mathrm{n}=16)$ fue: contacto táctil, corridas, contacto visual, mordiscos y exploración. Comparativamente, estos cachorros realizaron más actividades como tironear y recuperar objetos $(\mathrm{p}<0,01)$, y mostraron más interés que los ejemplares de fox terrier por roer plantas ornamentales y césped $(\mathrm{p}<0,05)$. Clasificando la frecuencia de eventos, los cachorros fox terrier $(\mathrm{n}=16)$ realizaron las actividades siguientes: correr, efectuar contacto táctil y visual, explorar y perseguir. Las actividades sociales de contacto visual, carrera y persecución fueron significativamente mayores en la raza fox terrier $(p<0,01)$. Al considerar las actividades individuales surgió que los cachorros fox terrier mostraron más interés en explorar el jardín que los beagles $(\mathrm{p}=0,01)$. En esta edad, las conductas naturales o espontáneas observadas, podrían constituir un acercamiento a los modelos de futuros comportamientos, revelando diferencias entre el género y las razas estudiadas.

Palabras clave: perro, comportamiento, actividades individuales y sociales, diferencias entre sexos y razas.

\section{INTRODUCTION}

Puppy adoption would be an act that might be much evaluated. Physical conditions such as sight or breed are taken into account, but the temperament is also an important fact. A number of tests on young dogs have been performed in order to evaluate the effects of different environmental conditions. The most popular test was performed by Campbell in 1972, who described puppies' social behaviors and their curiosity before adoption ${ }^{4}$, but much tests had been elaborated in order to predict adult behaviors $5,20,22,26$. But the owners do not know these tests and the selection would be done watching the way that the puppies play. Play could empirically say not only something about the dog but it is also associates to risk factors for dog bite ${ }^{10}$.

At 45 days old, the play behaviour occupied a large part of their activities. In free-ranging dogs it was observed that the play behaviour developed in three subsequent stages such as social play, agonistic play, and pseudo-sexual activity; at 3,5 and 6 weeks, ${ }^{1,9}$. Playful interactions increased with the age of the puppies to establish a stable social hierarchy, and suddenly decreased between 8 and 10 weeks of life ${ }^{15}$. These early life experiences are known to shape the behavioural development of animals and persist during the life ${ }^{6}$.

The present study was designed to investigate if there is any play behaviour difference in beagles and fox terriers puppies breaded in the same kennel. Objects' play and social play between siblings were compared considering not only the breed but also the gender.

\section{MATERIAL AND METHODS}

Study subjects. A total of 32 puppies ( $\mathrm{n}=16$ of each breed) from 6 different litters were observed. The puppies were between 40 and 45 days old $(n=32$; mean age $42.22 \pm$ SD 1.79 days) and lived with their mothers till the moment of the study. Mothers belong to a kennel, but during nursing, each bitch remained with her litter in a wired cage placed inside the kennel's house, having access to the garden four times a day. Weaning started when puppies were fourth week's old, receiving commercial puppy food and water ad libitum. All the animals received the same experimental conditions.

Study site and filming procedure. The recording sessions were completed in real-time mode and took place in Corrientes City, Argentina (S58 $49^{\prime}-\mathrm{W} 27^{\circ} 28^{\prime}$; $\pm 22^{\circ} \mathrm{C}$ average annual temperature and $\pm 1,500 \mathrm{~mm}$ average annual precipitation). These sessions were recorded using a portable camera (Sony DCR-DVD 108 manufactured in China) in a garden in the puppies' home, surface area of $18 \mathrm{~m}^{2}$, with grass and ornamental plants. Each session lasted between 10 and $15 \mathrm{~min}$. To avoid influences of circadian rhythm on activity patterns, all sessions were recorded at 12:00 h. The cameraman was out of the puppies' sight to avoid interspecific communication. The sessions were filmed without the mothers in order to obtain only sibling relationship occurrences. To identify the puppies more easily, coloured collars were used. The puppies had habituated to the collars a week before the experiment.

Data collecting. Filming sessions were of 15 minutes, covering all the area where the puppies were playing without a blind spot. In this way, all the puppies were filming at the same time. Then, each individual was observed from a PC monitor using a focal, direct and continuous sampling. Variables of behavioural patterns were recorded as occurrence frequency according to the designed ethogram (Table 1), which included both social play and environmental exploration activities. Because each recording session was observed twice, a concordance index was applied with to validate the two observations of the same observer ${ }^{2}$. In concordance 
Table 1. Ethogram for variables registered during sessions.

\begin{tabular}{|c|c|c|}
\hline activity & variable & description \\
\hline social & $\begin{array}{l}\text { visual } \\
\text { contact }\end{array}$ & $\begin{array}{l}\text { two subjects performed visual contact simultaneously and were registered for both puppies on each } \\
\text { correspondent focal sampling }\end{array}$ \\
\hline “ & $\begin{array}{l}\text { tactile } \\
\text { contact }\end{array}$ & $\begin{array}{l}\text { one subject executes tactile contact to other puppy via front paws or any other body part by several } \\
\text { communicative ways such as licking, touching or pushing }\end{array}$ \\
\hline “ & race & suddenly race episode performed from one point to other during a play context \\
\hline “ & jump & jumping performed by raising front paws or four legs during a play context \\
\hline “ & bite & $\begin{array}{l}\text { one subject bites a partner at least during } 3 \text { seconds. If time was shorter, it was considered as tactile } \\
\text { contact }\end{array}$ \\
\hline “ & chase & one subject runs in same direction as their partner performing a pursuit event \\
\hline “ & pull & $\begin{array}{l}\text { two subjects simultaneously hold with their teeth any object and pulling each other, performing } \\
\text { competence to win individual possession }\end{array}$ \\
\hline “ & win & $\begin{array}{l}\text { one subject achieves object possession after competition (pull) with a partner and may or not retain } \\
\text { it into the mouth for few seconds }\end{array}$ \\
\hline individual & gnaw & $\begin{array}{l}\text { repeatedly gnawing an object founded in the garden, such as leaves, grass, sticks or others, perfor- } \\
\text { ming chewing behaviour }\end{array}$ \\
\hline “ & exploration & walking and watching the area using mainly the visual sense \\
\hline “ & sniff & $\begin{array}{l}\text { smell the grass, air, and whatever they found in the place by taking air in through the nose at least } \\
\text { during } 3 \text { seconds. If time was shorter it was considered exploration }\end{array}$ \\
\hline
\end{tabular}

with this index, two measures were obtained. The lowest value was divided by the highest one, and the result was multiplied by 100 . The minimum percentage of agreement tolerated was $90 \%$.

Ethical note. All procedures and sample collections were conducted in accordance with the ethical guidelines of the Ethic and Biosecurity Committee of the College of Veterinarian Medicine, Northeast National University, Corrientes, Argentina). (Protocolo 004/12)

Statistical analysis. Thirty-two individuals from six litters were observed $(\mathrm{n}=32)$. A nonparametric statistical analysis was performed. Moreover, a MannWhitney $U$ test was used to compare breed and sex. Infostat V.10 package was used. The alpha error was set at $\mathrm{p}=0.05$.

\section{RESULTS}

Play activity distribution. Activities were divided in social, when the action take part into two or more puppies, and individual, when only one puppy was involve. At 45 days old, 8 types of social activities (visual contact, tactile contact, race, jump, bite, chase, pull, win) and 3 types of individual situation (gnawing, exploring, sniffing) were registered. Of all contact $(1,269)$, we identified 875 (76.48\%) as social activities and 394 (23.51\%) as individual activities.

Sex comparisons for social and individual activities. Only one activity was statistically different between the sexes: sniffing; the females sniffed the environment more often than the males (Mann-Whitney U-test, $\left.\mathrm{N}_{\text {female }}=18, \mathrm{~N}_{\text {male }}=14 ; \mathrm{U}=141.5, \mathrm{p}<0.007\right) . \mathrm{Al}$ - though the other variables revealed no significant differences when comparing sexes, there was a tendency females' puppies did more visual contact and tactile contact than the males.

Social and individual activities breed comparison. In both breeds, social activities occurred more frequently than individual activities $(\mathrm{p}=0.96)$. The breeds show differences during the playing activities (Figure 1). The ranking of activities for beagle puppies $(n=16)$ according of occurrence of frequency was contact tactile, races, visual contact, bite and explore. When comparing activities, beagles performed more activities as pulling and winning objects (Mann-Whitney U-test, $\mathrm{N}_{\text {beagle }}=16, \mathrm{~N}_{\text {fterrier }}=16$; pull: $\mathrm{U}=335$; win: $\mathrm{U}=304$, both

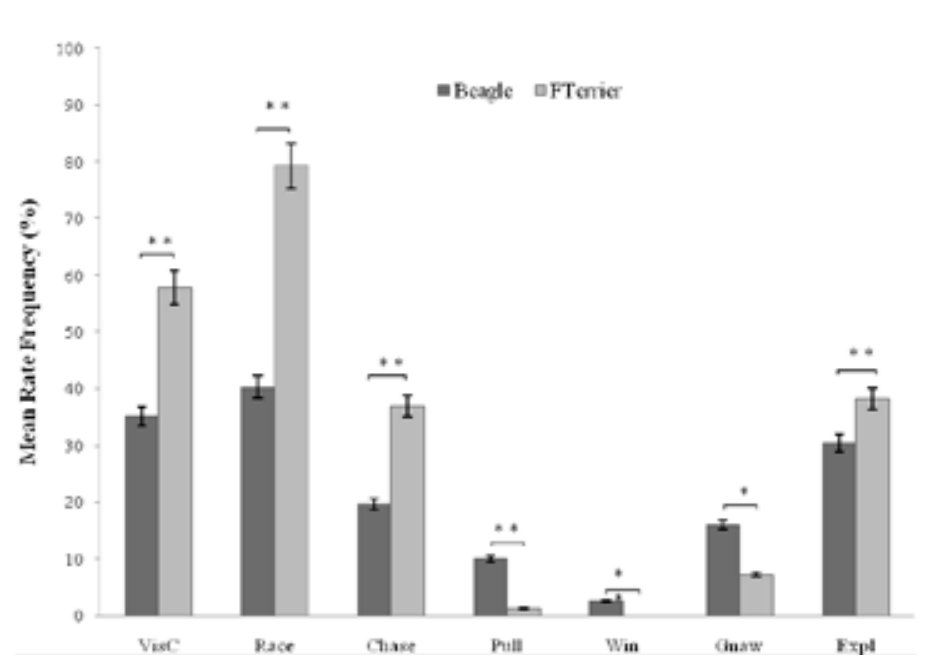

Figure 1. Percentages of mean rate frequency $( \pm$ percentage error) for social and individual activities for beagle and fox terrier breeds. The figure only shows activities that were significantly different between breeds (Mann-Whitney U test). In asterisks ${ }^{*} \mathrm{p}<0.05,{ }^{* *} \mathrm{p} \leq 0.01$. VisC: visual contact. Expl: exploration. 
$\mathrm{p} \leq 0.01$ ), and they showed higher interest in gnawing ornamental plants and grass $(\mathrm{U}=315.5, \mathrm{p}<0.05)$ than the fox terriers. Ranking in occurrence frequency, the fox terrier puppies $(n=16)$ performed the following activities: race, tactile contact, visual contact, explore and chase. Social activities of visual contact, race and chase were more significant in fox terrier puppies (Mann-Whitney U-test, visual contact: $U=199.5$, race: $\mathrm{U}=174.5$, chase: $\mathrm{U}=198.5$, all $\mathrm{p} \leq 0.01)$. When considering individual activities they were more interested in exploring the garden than the beagles $(U=203, p=0.01)$.

\section{DISCUSSION}

During the play in a familiar environment, significant differences for social and individual activities were observed between beagle and fox terrier puppies, but there was no difference between genders. It is well accepted that in the domestic dog, the mother should be at least till the eight weeks ${ }^{9}$ because during this time puppies will learn intraspecific communication and social hierarchies ${ }^{19}$, but we must considered that siblings also influence the social and behavioural development of the individuals, since a litter usually behaves like a miniature pack ${ }^{9,21}$.

Breed comparisons for social and individual activities. The beagle puppies scored higher in play behaviour associated with competition, such as pulling and winning. There is an absence of well-defined hierarchies at 6 weeks of age in domestic dogs; however, this type of play would indicate "hierarchy" relationships between siblings. In a quanti-qualitative comparative study of social play, the focal dog altered its interest to objects (toys) according to the partner ${ }^{17}$. For instance, the focal dog was strongly motivated by winning the object when the partner was a dog; in contrast, when the partner was a human (who was familiar to the focal dog) the focal dog showed a greater willingness of leaving the toy to start a new game. In both cases, the dogs showed different motivations and modified the playing structure according to the type of partner.

Beagle dogs are classified as hounds (6 groups for FCI, Fédération Cynologique Internationale), which usually hunt independently from humans with no continuous visual contact with their partner while searching for prey ${ }^{23}$. Moreover, hounds are less receptive to obedience trainability ${ }^{7,23}$. However, this breed has the highest score in sociability among conspecifics ${ }^{23}$. The competence during object play observed in the beagles in this study indicates early signs of future attitudes of individuals towards conspecifcs related to possible dominance hierarchies and resource competition. This observation matched with the observation of agonistic interaction between stray dogs in India ${ }^{16}$.

Fox terrier puppies showed higher interest in racing and chasing among siblings. The activities were consistent with the types of activities that were typically observed with terriers (3 groups for FCI). In particular, terriers are described as energetic, excitable and reactive. Even though they usually have a high score on boldness, they usually score lower than the average in dog sociability ${ }^{23}$.

Although all of the puppies were around the same age, some differences were found among the breeds regarding gnawing and exploring. Deciduous teeth eruption began at 5 weeks old. Therefore, all of the individuals were expected to invest equal amounts of time in gnawing ${ }^{16}$, since oral exploration also provides information about the texture, flavour and smell of objects ${ }^{13}$. However, beagles had higher scores than the fox terrier puppies for this activity. For garden exploring activities, the fox terrier puppies surprisingly scored higher than the beagles, which were possibly related to differences in the breed traits ${ }^{23}$. Therefore, breed differences would explain the exploratory preferences observed, namely, oral for beagles and searching for fox terriers. In addition to the exploration techniques chosen by the individuals, all of the techniques provided environmental information for future application, which will allow each individual to adapt to the environment ${ }^{3}$.

Another topic of interest were the traits that underlie each breed. In fact, selective breeding affects the structure of development, namely, the speed of maturation, duration of developmental behaviour periods and the sequence of how behaviours emerge ${ }^{12}$. However, although genes modulate the typical behavioural pattern among breeds, the no heritable "environmental factors" also would affect individuals ${ }^{26}$. These include external components such as weather, interactions with other organisms, litter size, litter sex distribution ${ }^{26}$ and the owner behaviour. The internal components include nutritional level, hormones and pathogens. All of these components could vary among individuals and contexts $5,8,18,21,23-26$. Therefore, an individual's behaviour would result from multifactorial events, in which multiple genes combining with environmental factors modify the phenotype of the individual ${ }^{8}$.

Sex comparisons for social and individual activities. In this study, no significant differences were observed between the sexes in social activities related to tactile contact, racing, jumping, biting, chasing or object competition. These results might be the consequence of puppies at six weeks of age which are not sexually mature ${ }^{18}$. With stray dogs, males scored higher than females for playing episodes and were bolder and more curious ${ }^{14-16,21}$. Conversely, other authors described higher frequencies for object activity in eightweek-old german shepherd females ${ }^{26}$. There were no differences in who started the game with the opposite sex (either male or female), except in the case of aggressive games, which were frequently initiated towards siblings of the same sex. Similar results were obtained with german shepherds where the males were keener on playing, more curious and a little more aggressive and cheeky than females ${ }^{21}$. 
With regards to individual activities, females scored higher in sniffing the environment. Eightweek-old german shepherd females showed a greater frequency in both individual and social activities with objects ${ }^{26}$. In this study, the distribution of sex tended towards females, which was the reason why it would be advisable to increase the number of animals to verify these observations.

In conclusion, despite the several behavioural prediction tests that are actually applied, the observations of natural or spontaneous behaviours consist of an approach of animal personality. Predicting future potential behavioural patterns in puppies implied different applications for breeders and trainers that allows to invest efforts to be concentrated mainly on suitable individuals $^{7,12}$. Although the predictive value of behavioural studies increases with sexual and social maturation $5,12,18,26$, this study found breed differences at six weeks of age in domestic dogs. The results agreed with the general traits described for each FCI group (hound and terriers) ${ }^{11}$. However, further research on puppy litters is needed to allow comparative studies for several traits that were not detected here, as well as to extend comparisons among breeds for puppies that remained in mainly intraspecific contact.

Acknowledgements. This research was financially supported by Secretaría General de Ciencia y Técnica, Universidad Nacional del Nordeste, PI B012/2010. The authors are grateful to María Victoria and Belén Rossner for statistical advice.

\section{REFERENCES}

1. Bekoff M. 2001. Social play behaviour. J Conscious Stud 8: 81-90.

2. Bentosela M, Barrera G, Jakovcevic A, Elgier AM, Mustaca AE. 2008. Effect of reinforcement, reinforcer omission and extinction on a communicative response in domestic dogs (Canis familiaris). Behav Process 78: 464-469.

3. Boissy A, Manteuffel G, Bak M, Moe RO, Spruijt B, Keeling LJ, Winckler C, Forkman B, Dimitrov I, Langbein J, Bakken M, Veissier I, Aubert A. 2007. Assessment of positive emotions in animals to improve their welfare. Physiol Behav 92: 375-397.

4. Campbell WE. 1972. A behaviour test for puppy selection. Mod Vet Pract 12: 29-33.

5. Diederich C, Giffroy JM. 2006. Behavioural testing in dogs: A review of methodology in search for standardization. Appl Anim Behav Sci 97: 51-72.

6. Foyer P, Bjallerhag N, Wilsson E, Jensen P. 2014. Behaviour and experiences of dogs during the first year of life predict the outcome in a later temperament test. Appl Anim Behav Sci 155: 93-100.

7. Houpt KA. 2007. Genetics of canine behavior. Acta Vet Brno 76: 431-444.

8. Jazin E. 2007. Behaviour genetics in canids, In: The Behavioural Biology of Dogs (Jensen P Ed), CABI Publishing, UK, p. 76-90.
9. Lindsay SR. 2000. Handbook of Applied Dog Behaviour and Training. Adaptation and Learning, vol. 1, Iowa State University Press, Iowa, USA, $410 \mathrm{p}$.

10. Messam LL, Kass PH, Chomel BB, Hart LA. 2012. Risk factors for dog bites occurring during and outside of play: Are they different? Prev Vet Med 107: 110-120.

11. Mehrkam LR, Wynne CD. 2014. Behavioral differences among breeds of domestic dogs (Canis lupus familiaris): Current status of the science. Appl Anim Behav Sci 155: 12-27.

12. Miklósi Á. 2007. Dog Behaviour, Evolution and Cognition, Oxford University Press, Oxford, USA, $304 \mathrm{p}$.

13. Muller G. 2006. Papel social del alimento y patologías del comportamiento relacionadas con la alimentación en el perro. In: Enciclopedia de la nutrición clínica canina (Pibot P, Biourge V, Elliott D Ed.), p. 482-491.

14. Pal SK, Ghosh B, Roy S. 1998. Agonistic behaviour of free-ranging dogs (Canis familiaris) in relation to season, sex and age. Appl Anim Behav Sci 59: 331-348.

15. Pal SK. 2008. Maturation and development of social behaviour during early ontogeny in free-ranging dog puppies in West Bengal, India. Appl Anim Behav Sci 111: 95-107.

16. Pal SK. 2010. Play behaviour during early ontogeny in free-ranging dogs (Canis familiaris). Appl Anim Behav Sci 126: 140-153.

17. Rooney NJ, Bradshaw JW, Robinson IH. 2000. A comparison of dog-dog and dog-human play behaviour. Appl Anim Behav Sci 66: 235-248.

18. Seksel K, Mazurski EJ, Taylor A. 1999. Puppy socialisation programs: short and long term behavioural effects. Appl Anim Behav Sci 62: 335-349.

19. Seksel K. 2010. La socialización del cachorro. Vet Focus 22: 7-12.

20. Sforzini E, Michelazzi M, Spada E, Ricci C, Careznzi C, Milani S, Luzi F, Verga M. 2009. Evaluation of young and adult dogs' reactivity. $J$ Vet Behav 4: 3-10.

21. Strandberg E, Jacobsson J, Saetre P. 2005. Direct genetic, maternal and litter effects on behaviour in german shepherd dogs in Sweden. Livest Prod Sci 93: 33-42.

22. Svartberg K. 2006. Breed-typical behaviour in dogs. Historical remnants or recent constructs? Appl Anim Behav Sci 96: 293-313.

23. Turcsán B, Kubinyi E, Miklósi Á. 2011. Trainability and boldness traits differ between dog breed clusters based on conventional breed categories and genetic relatedness. Appl Anim Behav Sci 132: 61-70.

24. Ward C, Bauer EB, Smuts BB. 2008. Partner preferences and asymmetries in social play among domestic dog, Canis lupus familiaris, littermates. Anim Behav 76: 11871199.

25. Wechsler B, Lea SE. 2007. Adaptation by learning: Its significance for farm animal husbandry. Appl Anim Behav Sci 108: 197-214.

26. Wilsson E, Sundgren PE. 1998. Behaviour test for eightweek old puppies. Heritabilities of tested behaviour traits and its correspondence to later behaviour. Appl Anim Behav Sci 58: 151-162. 